\title{
An Impact Assessment of Expected Future Turmoil Risk on FDI: A Panel Data Analysis of Developing Countries
}

\section{Mahvish Faran*}

\begin{abstract}
This paper uses foreign direct investment (FDI) data from 39 developing countries for the period 2002-11 to explore whether the expected future turmoil risk of a country plays a significant role in determining FDI. It concludes that countries for which the expected future turmoil risk is very high are likely to have lower FDI inflows than countries for which the expected future turmoil risk is low, keeping all other factors constant. The results also illustrate that GDP per capita, democratic accountability, religious tension, and FDI inflows in the previous period are important determinants of FDI in developing countries.
\end{abstract}

Keywords: Political risk, foreign direct investment, expected future turmoil risk.

JEL classification: C23, C33, F21, F23.

\section{Introduction}

Foreign direct investment (FDI) is seen as an engine of growth, especially for developing countries, which are keen to attract FDI in order to increase their investable resources and capital formation. FDI is also a means of transferring technology, innovative capacity, and managerial and operational skills to developing economies. It has become an important source of private external finance for developing economies because it is more resilient to economic crises as opposed to short-term credit and portfolio investments, which may be reversed quickly due to changes in the economic environment or investor perceptions. The share of FDI in GDP has also increased substantially for developing countries, from a low 0.1 percent in 1980 to 2.8 percent in 2012 (United Nations Conference on Trade and Development [UNCTAD], n.d.). FDI in developing economies has increased considerably over the last 25 years, rising from US\$ 296 billion in 1980 to US $\$ 7,744$ billion in 2012 (UNCTAD, n.d.).

\footnotetext{
${ }^{*}$ Visiting faculty, Lahore School of Economics, Pakistan.
} 
Multinational corporations (MNCs) take various economic and political factors into account when deciding where to invest, such as the expected returns to investment, how easily they can exit the host country if the security of their property is threatened, infrastructure availability, market size and growth, and the host country's macroeconomic stability and level of political risk.

According to a survey of 602 senior multinational executives, conducted by the Economist Intelligence Unit in 2007, political risk is seen as a greater obstacle to investment than corruption and infrastructural constraints. The Multilateral Investment Guarantee Agency (2012) suggests that, in the medium term, investors are most wary of political risk when making decisions about FDI. Figure 1 illustrates the positive correlation between FDI inflows per capita and the political risk rating variable from the Political Risk Services (PRS) Group's International Country Risk Guide. The relationship indicates that a higher political risk rating will induce positive FDI inflows, i.e., countries with a lower level of political risk are likely to attract more FDI inflows.

Figure 1: FDI per capita and political risk rating

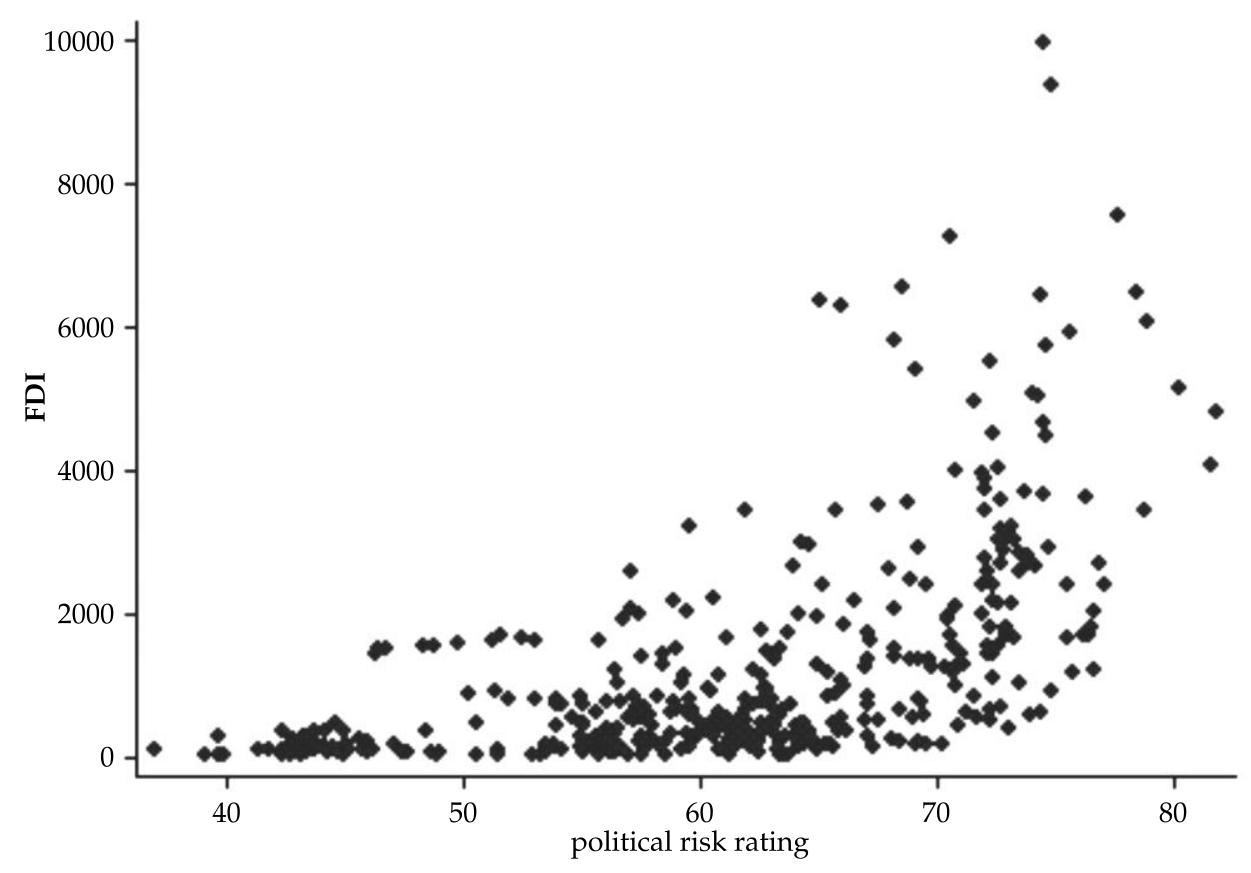

While the definition of political risk remains widely debated, Weston and Sorge (1972, p. 60) characterize it comprehensively as the 
... Risks that can arise from actions of national governments which interfere with or prevent business transactions or change the terms of agreement or cause confiscation of wholly or partially foreign owned property.

Today, political risk has become a greater cause for concern for investors following the liberalization of various FDI regimes in the 1990s. Recent global developments such as terrorist threats, economic crises, and developing countries' desire to control their natural resources have led to an increase in investor perceptions of political risk. Moreover, turbulent economic conditions in Europe, the Middle East, and the US, and the global shift in FDI toward emerging and developing countries (which accounted for 40 percent of FDI in 2011) have amplified investors' concerns about political risk.

Hashmi and Guvenli (1992) note that US multinationals are likely to face increasing risk in two areas: delays in profit repatriation and unilateral changes in rules by governments. US multinationals are expected to face an increasing number of threats, which is likely to affect their ability to conduct business in host countries. However, Sethi (1986) argues that the bargaining power of developing countries will decline in the future, which will lead to a decrease in future political risk.

Wilkins and Minor (2001) emphasize the need to view political risks in the 21st century from a new perspective:

Today's political risks are not the classic risks associated with communist takeovers or postcolonial outbursts of antiforeign sentiment. They are more subtle, arising from legal and regulatory changes, government transitions, environmental and human rights issues, currency crisis and terrorism. Because these risks are subtle (often occurring at the same time as the government is declaring the country "open for business") they are often hard to manage.

Dunning (1973) suggests that economic variables such as market size and growth, cost factors, and investment climate are the prime indicators of FDI inflows, while political variables are less important. Agarwal (1980) considers other economic factors such as investment incentives, infrastructure, market distances, economic stability, and market growth as the main determinants of FDI flows, and finds mixed results regarding the impact of political stability on FDI. Within the framework of 
survey studies, Robinson (1961), Basi (1963), Swansbrough (1972), and Root (1978) underscore the negative link between political instability and FDI inflows. Reuber, Crookell, Emerson, and Gallais-Hamonno (1973) and Piper (1971), however, observe that political variables are of minimal importance to investors.

Among cross-country studies on the subject, Levis (1979) finds a negative relationship between FDI and political instability, while Bennett and Green (1972), Green and Cunningham (1975), and Kobrin (1976) suggest that this relationship stands up to scrutiny. Agarwal (1980) notes that the inconsistency of the results emerges not only due to the different types of data and analytical methods, but also because the definition of political instability varies across different studies. Moreover, political instability does not always increase political risk for FDI, for example, in the case of a shift of power from an extreme left-wing government to a right-wing dictatorship. Gastanaga, Nugent, and Pashamova (1998) use a sample of 22 developing countries to illustrate how stronger institutional indicators such as lower corruption and better contract enforcement lead to a greater inflow of FDI.

Schneider and Frey (1985) argue that, in developing countries, FDI is determined by both economic and political factors such that economies at a higher level of development-signaled by a higher GDP per capita and a lower balance of payments-are likely to attract more FDI, while political instability and the amount of bilateral aid flowing in from the West are the most important political determinants of the direction of FDI. The authors conclude that an investor in an industrialized economy will tend to invest in a developing economy if the return expected from the latter is greater than that expected at home or in other industrialized countries. In many cases, economic conditions might seem to be favorable but investment may not take place due to hostile political conditions. This implies that it is important to consider both economic and political indicators of FDI.

The theory of international production suggests that foreign investors have a long-term horizon while making an investment decision in a host country. Jensen and Young (2008) and Li (2006) observe that FDI is often seen as a long-term decision because disinvestment is costly. Firms rely heavily on the expected probability of political violence; rational expectations and uncertainty on the part of foreign investors affects the ways in which political violence influences investment behavior (Li, 2006). 
The literature thus presents an interesting puzzle regarding the impact of political risk and stability on FDI inflows, given the conflicting results yielded by econometric studies and survey evidence. It is important to study the relationship between political risk and FDI in order to gain a better theoretical understanding of international production. This paper attempts to augment the literature by examining how expectations of various future political scenarios affect FDI inflows in developing countries-in doing so, we also employ a unique measure of expected future turmoil risk.

Li's (2006) analysis of the impact of predicted occurrences of anticipated and unanticipated scenarios focuses on three extreme forms of political violence: civil war, interstate war, and transnational terrorism. The study suggests that anticipated political violence might render an otherwise attractive investment location undesirable, thereby reducing reinvestment. The changes in investment decisions that occur before the event happens, however, may end up having little effect on FDI inflows after the event has actually taken place.

While Li (2006) considers extreme forms of political violence, the measures of expected future turmoil risk in this paper take into account not only expected scenarios that might lead to a state of war, but also scenarios involving occasional acts of violence and other obstacles that could seriously hinder business operations.

This paper builds on the following elements. First, political risk in the host country is an important variable in investment decisions. Second, forward-looking investors constantly anticipate the effect of turmoil risk in the host country. Third, expected future turmoil risk comprises four degrees: low, moderate, high, and very high. We aim to combine the behavior of forward-looking investors with respect to political risk with other economic and political determinants of FDI to illustrate whether the expected future political scenario of a country is a significant determinant of FDI or if economic and other political determinants remain the key indicators of FDI as shown by previous studies.

\section{Methodology}

This section describes the data and variables used, and specifies the study's model. 


\subsection{Data and Variables}

The analysis spans the period 2002 to 2011 for a sample of 39 developing countries. ${ }^{1}$ Busse and Hefeker (2007) use the political risk indicators provided by the International Country Risk Guide for a sample of 82 developing countries, and conclude that government stability, law and order, internal and external conflict, ethnic tension, bureaucratic quality and, to a lesser extent, democratic accountability and corruption determine the investment decisions of MNCs. However, data on expected future turmoil risk was available for only 39 of the 82 countries and the political risk country reports that contain information on expected future turmoil risk were not available before 2002. This paper uses a recent dataset and adds a new aspect to the subject by incorporating a unique measure of expected future turmoil risk and assessing its impact on FDI.

FDI net inflows, i.e., inflows net of outflows per capita, serve as the dependent variable and are measured in US dollars at current prices and exchange rates. Per capita values are used to account for the relative country size. FDI refers to foreign investments for which MNCs possess 10 percent or more of an enterprise in a host country. Given that this threshold is arbitrary and the FDI data does not include investment that is financed through equity or debt in the local market, it is possible that the model might underestimate the true value of investment by MNCs. If this bias is uniform across the sample, however, then the results are not likely to change, although the size of the coefficients may be overestimated. The data on FDI has been taken from the UNCTAD database.

Information on the political risk indicators is taken from the PRS Group's International Country Risk Guide and Country Risk Report, which provide data on 12 risk indicators, including political risk and other institutional indicators that are used to compute the political risk rating of a country. The relationship between the political risk rating and FDI is expected to be strong and positive. Kolstad and Villanger (2008), Singh and Jun (1995), and Harms (2002) have also used composite political economy indices. The 12 indicators that are used to compute the political risk rating are explained below.

\footnotetext{
${ }^{1}$ The country sample includes Algeria, Argentina, Bolivia, Brazil, Bulgaria, Cameroon, Chile, China, Colombia, Costa Rica, Cote d'Ivoire, Ecuador, Egypt, Guatemala, Guinea, Haiti, Honduras, India, Indonesia, Kenya, Malaysia, Mexico, Morocco, Nicaragua, Oman, Pakistan, Panama, Paraguay, Peru, the Philippines, Russia, Sri Lanka, Thailand, Tunisia, Turkey, Uruguay, Venezuela, Zambia, and Zimbabwe.
} 
1. Government stability: the government's ability to carry out its policies and remain in office (measured on a scale of $0-12$ ).

2. Socioeconomics: socioeconomic constraints to government action or factors that may amplify social discontent and thus weaken the political regime (measured on a scale of $0-12$ ).

3. Internal conflict: the degree of political violence in the country and its actual or potential consequences for governance, e.g., terrorism or civil war (measured on a scale of $0-12$ ).

4. Investment profile: factors related to the risk of investment, such as expropriation or delays in profit repatriation or payment (measured on a scale of $0-12$ ).

5. Corruption: the level of corruption in the country (measured on a scale of 0-6).

6. External conflict: the risk to the government from foreign action, ranging from diplomatic pressure to violent external conflicts (measured on a scale of $0-12$ ).

7. Religious tension: associated with attempts by one or more religious sects to dominate society and/or governance, to replace civil law with religious law, or to reduce the influence of other religions over the political process (measured on a scale of 0-6).

8. Law and order: the strength and impartiality of the legal system (measured on a scale of 0-6).

9. Ethnic tension: the extent of tension among ethnic groups arising from racial, national, or language divides (measured on a scale of 0-6).

10. Democratic accountability: the responsiveness of the government to its citizens with regard to civil liberties and political rights (measured on a scale of 0-6).

11. Bureaucratic quality: the institutional strength and quality of the bureaucracy, which acts to decrease the probability of policy revisions when governments change (measured on a scale of $0-4$ ).

12. Military in politics: the political influence of the military, which could signal that the government is not functioning efficiently and effectively and, therefore, that the country's environment for foreign businesses is unfavorable (measured on a scale of 0-6). 
The higher the value of these indicators, the lower will be the political risk, ${ }^{2}$ where the total number of points is 100 . The reason for including a composite index for political risk is that disaggregated indices can contain measurement errors, which may even out when the individual indices are combined. Disaggregated indices also vary less within countries over time, which makes them problematic to use. However, the major disadvantage of using a composite index such as this is that it does not provide useful policy implications because it contains numerous elements of the political system. The relationship between the political risk rating and FDI is expected to be positive: a higher index reflects lower risk.

To strike a balance between minimizing measurement errors and insufficient variation and obtaining meaningful policy measures, the political risk index is disaggregated into components that reveal distinct political economy characteristics and, hence, are more useful for determining policy implications. The index of institutional quality, for instance, includes socioeconomic conditions, government stability, corruption, bureaucratic quality, and law and order. Kolstad and Villanger (2008), Wei (2000), and Habib and Zurawicki (2002) suggest that various aspects of institutional quality are important in determining FDI.

The political stability index is computed by combining the indices for internal conflict, external conflict, religious tension, ethnic tension, and the military's political influence. Tuman and Emmert (1999) and Kolstad and Tøndel (2002) note that aspects of stability have a significant link with aggregate FDI. The model also includes an index for the risk associated with the country's investment profile, such as contract viability, profit repatriation, and payment delays. The relationship between these indices and FDI is expected to be positive.

Harms and Ursprung (2002) and Kolstad and Villanger (2008) draw a link between democracy and FDI. Accordingly, our model includes the index for democratic accountability. The relationship between democracy and FDI can be positive or negative: as Rodrik (1991) observes, democratic institutions can also be associated with unstable policies, e.g., when governments change in the normal course of an election or when timeinconsistent policies are introduced. Li and Resnick (2003) show that, after

\footnotetext{
2 According to the International Country Risk Guide's methodology, if the points awarded are less than 50 percent of the total, then that component is considered very high-risk. If the points fall within 50 and 60 percent, the component is considered high-risk. If the points are in the range of 70-80 percent, then the component is considered to carry a moderate risk. Points in the 80-100 percent range represent a low level of risk. Similar criteria are set for the composite political risk rating.
} 
taking into account a property rights measure, democracy decreases FDI inflows. The index for religious tension is included in the model to determine whether the involvement of religion in politics is a significant cause for concern among investors.

The PRS Group's country risk reports include information on each country's five-year forecasted turmoil risk. A dummy variable to account for the level of expected future turmoil risk is created using this data. The PRS Group defines "turmoil" as actions that might threaten or harm people or property, carried out by political groups or foreign governments operating within the country or externally.

The PRS Group is widely accepted as the most independent system of political risk forecasting and it presents different categories of forecasted turmoil risk, which have been used in this paper. The categorical variables created to measure the level of forecasted five-year turmoil risk range from low to moderate to high and very high. These variables are defined below:

- Low risk: discontent is expressed peacefully with a very low probability of political violence, which almost never affects MNCs.

- Moderate risk: occasional acts of terrorism, riots, political upheaval, labor unrest, or other forms of political violence.

- High risk: levels of political violence that may seriously hinder business operations.

- Very high risk: conditions that may lead to a state of war.

The model also includes other explanatory variables that are expected to have a relationship with FDI. GDP per capita, for instance, accounts for market size and is the most significant indicator of FDI inflows (Chakrabarti, 2001). The size of a market is likely to indicate the attractiveness of a location when an MNC is aiming to produce for the local market. GDP per capita is, therefore, expected to have a strong positive relationship with FDI. GDP is measured in current US dollars and the data has been obtained from the UNCTAD database.

Trade openness, which is also likely to have a strong impact on FDI inflows, is measured as the ratio of imports and exports to GDP. The relationship between trade openness and FDI is somewhat ambiguous: high trade barriers tend to attract horizontal FDI, while low trade barriers are associated with vertical FDI. Chakrabarti (2001) suggests, however, that trade openness and FDI are likely to have a positive relationship. The data 
on imports and exports is measured in US dollars at current prices and has been obtained from the UNCTAD database.

We include a lagged FDI variable to account for the fact that MNCs are likely to invest in countries that already have a substantial FDI inflow. The lagged FDI variable is, therefore, a significant determinant of FDI (Gastanaga et al., 1998; Jensen, 2003) and the relationship between FDI in the previous period and current period is expected to be strong and positive. Additionally, including a lagged dependent variable on the righthand side of the model helps reduce the problem of autocorrelation.

Countries with a consistent macroeconomic policy are also seen as a more viable option for investment: for example, inflation can be linked to monetary or fiscal policy imbalances and, hence, a lower inflation rate may be seen as reflecting an adequate macroeconomic policy. The variable for inflation denotes some negative values, which implies that it has to be transformed. ${ }^{3}$ Including the inflation rate also deflates all values given in current dollars. The data on the inflation rate has been taken from the World Development Indicators database. The inflation rate is expected to have a negative relationship with FDI inflows.

\subsection{Model Specification}

Table A1 in Appendix 1 provides descriptive statistics for the variables incorporated in the model. The initial regression employs fixed rather than random effects (see Table A2 in Appendix 1) based on the results of the Hausman test. However, this yields alarming results because the signs for political risk rating, institutional quality, political stability, investment profile, and religious tension are counterintuitive. Fixed effects assume that all the control variables and political risk indicators are exogenous, which is unrealistic.

We test for error autocorrelation by computing the Bhargava Durbin-Watson statistic, which is less than 1 for all regressions, indicating positive first-order serial correlation. The presence of autocorrelation implies that some or all of the estimated coefficients are biased, which could severely affect the interpretation of the impact of the independent variables on FDI. However, adding the lagged FDI variable to the righthand side of the equation reduces this problem significantly. We employ a dynamic panel specification for this purpose.

\footnotetext{
${ }^{3}$ The transformation equation is as follows: $y=\ln \left(x+\sqrt{x^{2}+1}\right.$
} 
Using the Arellano-Bond/Blundell-Bover GMM estimatordesigned for small $\mathrm{T}$ and large $\mathrm{N}$ panels, a dynamic left-hand side variable, independent variables that are not strictly exogenous, and heteroskedasticity and autocorrelation within, but not across, individualsallows us to control for the endogenous variables in the model. The inclusion of trade openness and GDP per capita in the regression analysis may lead to reverse causality. This would imply that trade openness affects FDI while higher FDI inflows are likely to lead to an increase in trading volume. Similarly, higher FDI is likely to increase the capital stock by introducing new technologies, thus raising GDP growth rates and hence GDP per capita.

The Arellano-Bond/Blundell-Bover GMM estimator addresses the issue of autocorrelation, making our estimates more reliable. Busse and Hefeker (2007) also employ this estimator when regressing the political risk indicators given in the International Country Risk Guide on FDI inflows for 82 developing countries from 1984 to 2003.

The benchmark regression model is written as

In $F D I_{i t}=B_{0}+B_{1} \ln G D P_{i t}+B_{2} \ln$ trade openness $i t+B_{3}$ political $_{i t}+B_{4}$ very high $_{i t-1}+B_{5}$ high $_{i t-1}+B_{6}$ moderate $_{i t-1}+B_{7} F D I_{i t-1}+B_{8}$ ln inflation $_{i t}+\varepsilon_{i t}$

Here, political denotes the indicators of political risk and institutions, while very high, high, and moderate indicate the corresponding levels of expected future turmoil risk. The political variables are added to the model one by one due to their correlation. FDI, GDP, and trade openness are transformed by taking the log to base 10, which is necessary to ensure the variables are normally distributed.

The model includes the lagged variables for very high, high, and moderate levels of expected future turmoil risk. The country risk reports and the risk forecasts that are used to create dummy variables for the given categories of expected future turmoil risk for a particular year are published in December. This implies that investors will consider the previous year's risk forecasts when making an investment decision. For example, the risk report for Haiti for 2011 was published in December 2011, meaning that investors will consider the forecasted five-year turmoil risk level for 2010 in order to make investment decisions for 2011. 


\section{Empirical Results and Analysis}

This section presents the results of the study.

\subsection{Analysis and Results}

The results of the dynamic panel estimation are reported in Table 1. The lagged FDI variable is significant at the 1 percent level in all the models estimated; this is the strongest level of significance and implies that a multinational's own success and the experience of other multinationals in the host country are strong indicators for future investment. In model 1, a one-percent increase in FDI in the previous period is expected to bring about a 0.68 percent increase in FDI in the current period, ceteris paribus.

The lagged variable for very high expected future turmoil risk has a negative relationship with FDI in all the models and is significant at the 5 percent level, indicating that countries with very high levels of expected future turmoil risk tend to have lower FDI inflows than countries with low levels of expected future turmoil risk, ceteris paribus. For example, in model 1, keeping all other factors constant, a country with a very high level of expected future turmoil risk has 16 percent lower FDI inflows than a country with a low level of expected future turmoil risk. Holding all other explanatory variables constant, on average the FDI inflows of a country with a very high level of expected future turmoil risk are 14.7 percent lower than the FDI inflows of a country with a low level of expected future turmoil risk (see Appendix 2 for the calculation of this proportionate difference).

This finding illustrates the forward-looking nature of investors and confirms the hypothesis that, even if current economic and political conditions seem favorable, expectations of a bleak political scenario (such as the threat of riots that might harm life and property) will deter investors from investing in that country. Turbulent political conditions are also likely to create hurdles for the daily operations of businesses and may also make it difficult for firms to exit the host country. Li (2006) supports this result and shows that anticipated events such as civil war, interstate war, and transnational terrorism are likely to render a site less attractive, limit expansion, and induce pre-emptive divestment.

GDP per capita maintains a positive relationship with FDI in all the models; GDP is significant at the 5 percent level in models 1 and 4 and at the 10 percent level in the other models. In other words, countries at a 
higher level of development, as indicated by a higher GDP per capita, received larger FDI inflows during 2003-11, ceteris paribus. The significance of the variable shows that a higher GDP per capita may signal higher investment returns and attract more FDI. For example, in model 1, an increase in GDP per capita of 1 percent will increase FDI inflows by 0.46 percent, keeping all other factors fixed.

The relationship between trade openness and FDI inflows is negative in all the models and significant only in model 1 when the composite political risk rating is added. The relationship derived in model 1 indicates that lower trade barriers tend to deter multinationals from investing in developing countries because an open economy is likely to be more competitive than one with higher barriers to trade, which would protect the output of foreign firms in the local market against their competitors' imports.

In model 1, an increase in trade openness of 1 percent will decrease FDI inflows by 0.35 percent, keeping all other factors fixed However, the results obtained from the other models support the findings of Busse and Hefeker (2007), who argue that FDI inflows in developing countries are unaffected by trade openness. Kolstad and Villanger (2008) also show that FDI inflows in the services industry are market seeking and unaffected by the trade openness of the host country.

Democratic accountability has a positive and significant relationship with FDI. The results indicate that a one-unit increase in democratic accountability will increase FDI inflows by 2.2 percent, ceteris paribus. Guerin and Manzocchi (2009), Harms and Ursprung (2002), Jensen (2003), and Busse (2004) also support the hypothesis that democratic countries are more likely to attract FDI.

The index for religion tension is significant at the 10 percent level and indicates that a lower risk of religious tension will have a positive impact on FDI. Keeping all other explanatory variables and factors fixed, an increase in this index of one unit will increase FDI by 4.9 percent. This result is in contrast to Busse and Hefeker (2007), who find that religious tension is an insignificant determinant of FDI.

It is important to note, however, that we have employed a relatively recent dataset and the corresponding analysis shows that investors have now become more concerned about religious involvement in politics: the level of religious tension does, therefore, matter to MNCs hoping to invest 
in developing countries. The onset of terrorism in the 21st century due to religious extremism in developing countries also explains why religion tension has become an important element of multinational investment decisions. High levels of religious activism are likely to hinder firms' operations and threaten their property and personnel, making such locations less attractive to multinationals.

The sign of the investment profile variable is as expected but is insignificant, which is surprising given that it includes elements such as the expropriation of assets and the ability to repatriate profits. Since the GMM estimator takes first differences and lags as instruments, this implies that improvements in the investment profile in previous periods are not closely linked to recent increases in FDI inflows. 
Table 1: Arellano-Bond/Blundell-Bover dynamic panel estimation, 2002-11

Dependent variable: $\ln$ FDI

\begin{tabular}{|c|c|c|c|c|c|c|}
\hline Explanatory variable & Model 1 & Model 2 & Model 3 & Model 4 & Model 5 & Model 6 \\
\hline Lagged FDI (LlnFDI) & $\begin{array}{l}0.68^{* * *} \\
(4.98)\end{array}$ & $\begin{array}{l}0.67^{* * *} \\
(4.99)\end{array}$ & $\begin{array}{l}0.67^{* * *} \\
(4.88)\end{array}$ & $\begin{array}{l}0.482^{* * *} \\
(3.01)\end{array}$ & $\begin{array}{l}0.65^{* * *} \\
(4.68)\end{array}$ & $\begin{array}{l}0.66^{* * *} \\
(4.53)\end{array}$ \\
\hline $\begin{array}{l}\text { Lagged moderate } \\
\text { expected future turmoil } \\
\text { risk (MOD) }\end{array}$ & $\begin{array}{l}-0.03 \\
(-0.80)\end{array}$ & $\begin{array}{l}-0.033 \\
(-1.26)\end{array}$ & $\begin{array}{l}-0.035 \\
(-1.36)\end{array}$ & $\begin{array}{l}-0.027 \\
(-0.81)\end{array}$ & $\begin{array}{l}-0.034 \\
(-1.22)\end{array}$ & $\begin{array}{l}-0.035 \\
(-1.34)\end{array}$ \\
\hline $\begin{array}{l}\text { Lagged high expected } \\
\text { future turmoil risk } \\
\text { (HIGH) }\end{array}$ & $\begin{array}{l}-0.014 \\
(-0.300)\end{array}$ & $\begin{array}{l}-0.15 \\
(-0.33)\end{array}$ & $\begin{array}{l}-0.14 \\
(-0.31)\end{array}$ & $\begin{array}{l}-0.059 \\
(-1.18)\end{array}$ & $\begin{array}{l}-0.02 \\
(-0.39)\end{array}$ & $\begin{array}{l}-0.010 \\
(-0.27)\end{array}$ \\
\hline $\begin{array}{l}\text { Lagged very high } \\
\text { expected future turmoil } \\
\text { risk (VHIGH) }\end{array}$ & $\begin{array}{l}-0.160^{* *} \\
(-1.97)\end{array}$ & $\begin{array}{l}-0.186^{* *} \\
(-1.98)\end{array}$ & $\begin{array}{l}-0.190^{* *} \\
(-2.20)\end{array}$ & $\begin{array}{l}-0.13^{*} \\
(-1.70)\end{array}$ & $\begin{array}{l}-0.175^{* *} \\
(-2.30)\end{array}$ & $\begin{array}{l}-0.166^{* *} \\
(-2.10)\end{array}$ \\
\hline $\begin{array}{l}\text { Log of GDP per capita } \\
\text { (GDP) }\end{array}$ & $\begin{array}{l}0.46^{* *} \\
(2.05)\end{array}$ & $\begin{array}{l}0.37^{*} \\
(1.69)\end{array}$ & $\begin{array}{l}0.38^{*} \\
(1.73)\end{array}$ & $\begin{array}{l}0.686^{* *} \\
(2.62)\end{array}$ & $\begin{array}{l}0.40^{*} \\
(1.70)\end{array}$ & $\begin{array}{l}0.36^{*} \\
(1.71)\end{array}$ \\
\hline $\begin{array}{l}\text { Log of trade openness } \\
\text { (TRADE) }\end{array}$ & $\begin{array}{l}-0.35^{*} \\
(-1.65)\end{array}$ & $\begin{array}{l}-0.29 \\
(-1.44)\end{array}$ & $\begin{array}{l}-0.27 \\
(-1.43)\end{array}$ & $\begin{array}{l}-0.37 \\
(-1.56)\end{array}$ & $\begin{array}{l}-0.29 \\
(-1.46)\end{array}$ & $\begin{array}{l}-0.28 \\
(-1.48)\end{array}$ \\
\hline $\begin{array}{l}\text { Inflation rate } \\
\text { (LNINFLATION) }\end{array}$ & $\begin{array}{l}-0.05 \\
(-0.77)\end{array}$ & $\begin{array}{l}-0.06 \\
(-0.81)\end{array}$ & $\begin{array}{l}-0.08 \\
(-0.88)\end{array}$ & $\begin{array}{l}-0.04 \\
(-0.71)\end{array}$ & $\begin{array}{l}-0.06 \\
(-0.82)\end{array}$ & $\begin{array}{l}-0.07 \\
(-0.77)\end{array}$ \\
\hline $\begin{array}{l}\text { Political risk rating } \\
\text { (POLRISK) }\end{array}$ & $\begin{array}{l}0.017 \\
(1.190)\end{array}$ & & & & & \\
\hline $\begin{array}{l}\text { Institutional quality } \\
\text { (INSTIT) }\end{array}$ & & $\begin{array}{l}0.008 \\
(0.820)\end{array}$ & & & & \\
\hline $\begin{array}{l}\text { Political stability } \\
\text { (POLST) }\end{array}$ & & & $\begin{array}{l}0.009 \\
(0.560)\end{array}$ & & & \\
\hline $\begin{array}{l}\text { Democratic } \\
\text { accountability } \\
\text { (DEMOC) }\end{array}$ & & & & $\begin{array}{l}0.022^{* *} \\
(2.270)\end{array}$ & & \\
\hline $\begin{array}{l}\text { Investment profile } \\
\text { (INVEST) }\end{array}$ & & & & & $\begin{array}{l}0.025 \\
(1.220)\end{array}$ & \\
\hline $\begin{array}{l}\text { Religious tension } \\
\text { (RELIG) }\end{array}$ & & & & & & $\begin{array}{l}0.049^{*} \\
(1.770) \\
\end{array}$ \\
\hline Groups & 39 & 39 & 39 & 39 & 39 & 39 \\
\hline Instruments & 25 & 25 & 25 & 25 & 25 & 25 \\
\hline Hansen test $X^{2}(18)$ & 24.85 & 26.06 & 27.15 & 26.89 & 28.60 & 25.75 \\
\hline Hansen p-values & 0.0014 & 0.09 & 0.089 & 0.056 & 0.065 & 0.13 \\
\hline $\mathrm{AB}$ test (z-values) & -0.0400 & -0.05 & -0.060 & -0.020 & -0.080 & -0.01 \\
\hline
\end{tabular}

Note: The results of the regression refer to one-step estimates; $z$-values are reported in parentheses; ${ }^{* *},{ }^{* *}$, and ${ }^{*}=$ significant at 1,5 , and 10 percent, respectively.

Source: Author's calculations.

The table employs difference GMM rather than system GMM. Although the latter improves efficiency, it also uses more instruments; given that the sample comprises 41 countries, system GMM is not an 
appropriate choice. The equation also employs robust standard errors and the Hansen statistic to test the validity of the instruments used.

The consistency of the Arellano-Bond/Blundell-Bover estimator requires the absence of second-order autocorrelation. The z-values of the Arellano-Bond $(\mathrm{AB})$ test given in Table 1 clearly indicate that the null hypothesis of no second-order autocorrelation is not rejected. Hence, there is no second-order autocorrelation in the model; autocorrelation of order one is always rejected (not reported). Since the p-value of the Hansen test is greater than the 5 percent level of significance, we do not reject the null hypothesis that the instruments are exogenous. We can therefore conclude that the instruments employed are valid and exogenous

\subsection{Robustness Checks}

To test the robustness of the results obtained, we run several regressions using all permutations of the explanatory variables (see Table A3 in Appendix 1 for the regression results for model 1). GDP per capita, very high expected future turmoil risk, lagged FDI, democratic accountability, and religious tension remain significant at the same level in all the regressions.

We also test whether the regression results obtained are sensitive to small changes in the sample size. For this purpose, Brazil, Russia, India, and China (BRIC) - the largest countries in the sample in terms of economy and population-are excluded. The new sample now contains 35 countries, most of which are small developing countries. The sample is altered in this way to determine whether our results are applicable to relatively small developing countries.

Once the BRIC countries have been removed from the sample, model 1 shows that GDP per capita is significant at the 10 percent level while very high expected future turmoil risk and lagged FDI remain significant at the 5 percent and 1 percent level, respectively (see Table A4 in Appendix 1 for the regression results). The magnitude of the impact of GDP per capita on FDI does not differ drastically from the initial results.

In model 2, lagged FDI and very high expected future turmoil risk are both significant at the 1 percent level while GDP per capita is significant at the 10 percent level. Surprisingly, moderate future expected turmoil risk becomes significant after excluding the BRIC countries: after controlling for institutional quality, the variable is significant at the 10 percent level, suggesting that countries with a moderate level of expected 
future turmoil risk are likely to have 3.7 percent lower FDI inflows than those with a low level of expected future turmoil risk, ceteris paribus.

Model 3 shows that lagged FDI, very high expected future turmoil risk, and GDP remain significant at the 1 percent, 5 percent, and 10 percent level, respectively. Moderate expected future turmoil risk was insignificant in the initial regression, but after controlling for political stability, it becomes significant at the 10 percent level. This suggests that countries with a moderate level of expected future turmoil risk are likely to have 4 percent less FDI than countries with a low level of expected future turmoil risk, ceteris paribus.

In model 4, GDP per capita becomes insignificant while very high expected future turmoil risk, lagged FDI, and democratic accountability remain significant. Moderate expected future turmoil risk, which was initially insignificant, is now significant at the 10 percent level. Countries with a moderate level of expected future turmoil risk are likely to have 4.1 percent less FDI than those with a low level of expected future political risk, keeping all other factors constant.

In model 5, lagged FDI and very high expected future turmoil risk are significant at the 1 percent level, while GDP per capita is significant at the 10 percent level. Moderate expected future turmoil risk is now also significant at the 10 percent level, suggesting that countries with a moderate level of expected future turmoil risk are likely to have 4.2 percent less FDI than those with a low level of expected future turmoil risk, ceteris paribus.

In model 6, lagged FDI and very high expected future turmoil risk are significant at the 1 percent level. Moderate expected future turmoil risk, which was previously insignificant, becomes significant at the 10 percent level. Countries with a moderate level of expected future turmoil risk are expected to have 4.7 percent lower FDI inflows than countries with a low level of expected future turmoil risk, ceteris paribus. Finally, religious tension is now significant at the 5 percent level.

Summing up, the models present evidence of a link between very high expected future turmoil risk and FDI that is robust to changes in sample size and variables. The relationship between FDI inflows and religious tension is also robust to changes in variables and sample size. Some regressions reveal an inverse relationship between moderate expected future turmoil risk and FDI. Given that the sample now contains relatively small developing countries, even occasional incidents of violence, 
labor unrest, and political upheaval may cause concern among investors deciding whether to invest in such countries. GDP per capita is robust to most changes in sample size and variables, but the level at which it is significant varies.

The results support the case that multinationals are discouraged by undemocratic regimes and more likely to be attracted to countries that maintain their citizens' political freedom. There is also a strong case for the hypothesis that multinationals tend to be attracted to countries with high FDI inflows, given that lagged FDI is robust to all changes in the sample and explanatory variables.

\section{Conclusion}

The study's results reveal that investors take into consideration not only the expected returns on their investment, which may depend on GDP per capita as an indicator of market size, but also on the expected level of future turmoil risk. Foreign investment in the previous period is also a significant determinant of current FDI inflows. The analysis confirms that economies that already host other MNCs and have the potential to absorb the output of additional MNCs producing for the local market are more likely to attract FDI.

The most important finding is that investors are likely to be wary of countries with very high levels of expected future turmoil risk, i.e., conditions that might lead to a state of war. War often results in regime changes, which are generally associated with the expropriation of assets and breaches of contract between MNCs and former regimes to the detriment of foreign investors. Political violence that leads to a state of war is likely to cause an economic recession in the host country, damage its infrastructure, and impose financial constraints on the government as it tries to tackle these issues, often exhausting substantial financial and human resources in the process.

The study provides strong evidence that religious tension is another important determinant of FDI. Attempts by one or more religious groups to replace civil law may threaten the host country's economic conditions and the security of investors' assets. An increase in religious tension in the host country is thus likely to dampen FDI inflows. In this study, the composite political risk rating has no statistically significant impact on FDI inflows, although we do find evidence that a more democratic regime is likely to induce FDI inflows. 
In order to boost investor confidence, governments should invest in the means of eradicating the root cause of political turmoil. In some developing countries, certain social groups may retaliate and join antigovernment forces to oppose the prevailing social inequality, thereby increasing the chances of civil war. To minimize this risk, governments should allocate greater funds to education, employment, and other civic facilities in order to remove anti-government sentiments and decrease the probability of a regime change. 


\section{References}

Agarwal, J. P. (1980). Determinants of foreign direct investment: A survey. Weltwirtschaftliches Archiv, 116(4), 739-773.

Basi, R. S. (1963). Determinants of United States private direct investment in foreign countries. Kent, OH: Kent State University Press.

Bennett, P. D., \& Green, R. T. (1972). Political instability as a determinant of direct foreign investment in marketing. Journal of Marketing Research, 9, 162-186.

Busse, M. (2004). Transnational corporations and repression of political rights and civil liberties: An empirical analysis. Kyklos, 57, 45-66.

Busse, M., \& Hefeker, C. (2007). Political risk, institutions and foreign direct investment. European Journal of Political Economy, 23(2), 397-415.

Chakrabarti, A. (2001). The determinants of foreign direct investment: Sensitivity analyses of cross-country regressions. Kyklos, 54, 89-113.

Dunning, J. H. (1973). The determinants of international production. Oxford Economic Papers, 25(3), 289-336.

Dutta, N., \& Roy, S. (2011). Foreign direct investment, financial development and political risks. Journal of Developing Areas, 44, 303-327.

Gastanaga, V. M., Nugent, J., \& Pashamova, B. (1998). Host country reforms and FDI inflows: How much difference do they make? World Development, 26(7), 1299-1314.

Green, R. T., \& Cunningham, W. H. (1975). The determinants of US foreign investment: An empirical examination. Management International Review, 15, 113-120.

Guerin, S. S., \& Manzocchi, S. (2009). Political regime and FDI from advanced to emerging countries. Review of World Economics, 145(1), 75-91.

Habib, M., \& Zurawicki, L. (2002). Corruption and foreign direct investment. Journal of International Business Studies, 33(2), 291-307. 
Harms, P. (2002). Political risk and equity investment in developing countries. Applied Economics Letters, 9(6), 377-380.

Harms, P., \& Ursprung, H. W. (2002). Do civil rights and political representation really boost foreign direct investments? Economic Enquiry, 40(4), 651-663.

Hashmi, M. A., \& Guvenli, T. (1992). Importance of political risk assessment function in US multinational corporations. Global Finance Journal, 3(2), 137-144.

Jensen, N. (2003). Democratic governance and multinational corporations: Political regimes and inflows of foreign direct investment. International Organization, 57(3), 587-616.

Jensen, N. (2008). Political risk, democratic institutions, and foreign direct investment. Journal of Politics, 70(4), 1040-1052.

Jensen, N., \& Young, D. J. (2008). A violent future? Political risk insurance markets and violence forecasts. Journal of Conflict Resolution, 52(4), 527-547.

Kobrin, S. J. (1976). The environmental determinants of foreign direct manufacturing investment: An ex post empirical analysis. Journal of International Business Studies, 7, 29-42.

Kolstad, I., \& Tøndel, L. (2002). Social development and foreign direct investments in developing countries (Report No. 2002: 11). Bergen: Chr. Michelsen Institute.

Kolstad, I., \& Villanger, E. (2008). Determinants of foreign direct investment in services. European Journal of Political Economy, 24(2), 518-533.

Levis, M. (1979). Does political instability in developing countries affect foreign investment flow? An empirical examination. Management International Review, 19, 59-68.

Li, Q. (2006). Political violence and foreign direct investment. In M. Fratianni \& A. M. Rugman (Eds.), Research in global strategic management (vol. 12, pp. 231-255). Cambridge, MA: Elsevier. 
Li, Q., \& Resnick, A. (2003). Reversal of fortunes: Democratic institutions and foreign direct investment inflows to developing countries. International Organization, 57(1), 175-212.

Lucas, R. E. (1993). On the determinants of foreign direct investment: Evidence from East and Southeast Asia. World Development, 21(3), 391-406.

Multilateral Investment Guarantee Agency. (2012). World investment and political risk 2012. Washington, DC: Author.

Piper, J. R. (1971). How US firms evaluate foreign investment opportunities. MSU Business Topics, 19, 11-20.

Political Risk Services Group. (2002-11). International country risk guide. East Syracuse, NY: Author.

Political Risk Services Group. (2002-11). Political risk yearbook. East Syracuse, NY: Author.

Ramcharran, H. (1999). Foreign direct investment and country risk: Further empirical evidence. Global Economic Review, 28(3), 49-59.

Reuber, G. L., Crookell, H., Emerson, M., \& Gallais-Hamonno, G. (1973). Private foreign investment in development. Oxford: Clarendon Press.

Robinson, H. J. (1961). The motivation and flow of private foreign investment. Menlo Park, CA: Stanford Research Institute.

Rodrik, D. (1991). Policy uncertainty and private investment in developing countries. Journal of Development Economics, 36(2), 229-242.

Roodman, D. (2009). How to do xtabond2: An introduction to "difference" and "system" GMM in Stata. Stata Journal, 9(1), 86-136.

Root, F. R. (1978). International trade and investment (4th ed.). Cincinnati, $\mathrm{OH}$ : South-Western Publishing.

Schneider, F., \& Frey, B. (1985). Economic and political determinants of foreign direct investment. World Development, 13(2), 161-175. 
Sethi, P. S. (1986). Changing rules of international corporate behavior. Paper presented at the Annual Meeting of the Academy of Management, Chicago, IL.

Singh, H., \& Jun, K. W. (1995). Some new evidence on determinants of foreign direct investment in developing countries (Policy Research Paper No. 1531). Washington, DC: World Bank.

Swansbrough, R. H. (1972). The American investor's view of Latin American economic nationalism. Inter-American Economic Affairs, 26(3), 61-82.

Tuman, J., \& Emmert, C. (1999). Explaining Japanese foreign direct investment in Latin America, 1979-1992. Social Science Quarterly, $80(3), 539-555$.

United Nations Conference on Trade and Development. (n.d.). Foreign direct investment [Database]. Retrieved from http:/ / unctadstat.unctad.org/ReportFolders/reportFolders.aspx? sRF_ActivePath $=\mathrm{p}, 5 \& \mathrm{sRF} \_$Expanded $=, \mathrm{p}, 5$

Wei, S.-J. (2000). How taxing is corruption on international investors? Review of Economics and Statistics, 82(1), 1-11.

Weston, F. V., \& Sorge, B. W. (1972). International managerial finance. Homewood, IL: Richard D. Irwin.

Wilkins, S., \& Minor, J. (2001). Managing today's political risks. Risk Management Letter, 22(6), 1-7.

Wooldridge, J. M. (2002). Introductory econometrics: A modern approach (2nd ed.). Cincinnati, $\mathrm{OH}$ : South-Western Publishing.

World Bank. (2014). World development indicators [Database]. Retrieved from http://data.worldbank.org/data-catalog/worlddevelopment-indicators 


\section{Appendix 1}

Table A1: Descriptive statistics of variables

\begin{tabular}{lccccc}
\hline Variable & $\mathbf{N}$ & Mean & SD & Min. & Max. \\
\hline Democratic & 390 & 3.795 & 1.537 & 0.00 & 6.00 \\
FDI & 390 & 1,242 & 1,546 & 11.72 & 9,945 \\
High & 390 & 0.288 & 0.453 & 0.00 & 1.00 \\
Institution & 390 & 20.01 & 4.227 & 8.70 & 30.50 \\
Political & 390 & 26.84 & 3.775 & 16.00 & 32.90 \\
Investment & 390 & 7.707 & 2.242 & 1.00 & 11.50 \\
Moderate & 390 & 0.459 & 0.499 & 0.00 & 1.00 \\
Religion & 390 & 4.419 & 1.462 & 0.00 & 6.00 \\
Very high & 390 & 0.0293 & 0.169 & 0.00 & 1.00 \\
Rating & 390 & 61.67 & 9.518 & 37.00 & 81.80 \\
GDP & 390 & 3,802 & 3,603 & 287.90 & 23,421 \\
Trade openness & 390 & 95.40 & 90.08 & 19.00 & 600.0 \\
Inflation & 390 & 8.060 & 7.630 & -21.44 & 74.30 \\
\hline
\end{tabular}

Source: Author's calculations.

The variables used in Tables A2 to A4 are listed below:

- $\quad$ Lln FDI = lagged FDI

- Moderate $=$ moderate expected future turmoil risk

- High = high expected future turmoil risk

- Very high = very high expected future turmoil risk

- $\quad$ Rating $=$ political risk rating

- $\mathrm{Ln}$ GDP = log of GDP per capita

- $\quad$ Trade $=\log$ of trade openness

- $\quad$ Ln inflation = inflation rate

- Institution = institutional quality

- Political $=$ political stability

- Democratic $=$ democratic accountability

- Investment = investment profile

- $\quad$ Religion $=$ religious tension 
Table A2: Panel data analysis with fixed effects

Dependent variable: $\ln$ FDI

\begin{tabular}{|c|c|c|c|c|c|c|}
\hline Independent variable & Model 1 & Model 2 & Model 3 & Model 4 & Model 5 & Model 6 \\
\hline \multirow[t]{2}{*}{ Ln GDP } & 3.42 & 4.12 & 3.56 & 3.45 & 3.26 & 4.22 \\
\hline & $(19.21)^{* * *}$ & $(18.50)^{* * *}$ & $(18.12)^{* * *}$ & $(20.90)^{* * *}$ & $(20.15)^{* * *}$ & $(21.90)^{* * *}$ \\
\hline \multirow[t]{2}{*}{ Trade } & 0.156 & 0.146 & 0.167 & 0.190 & 0.117 & 0.143 \\
\hline & $(1.05)$ & $(1.50)$ & $(1.23)$ & (1.15) & $(1.344)$ & (1.12) \\
\hline \multirow[t]{2}{*}{ Rating } & -0.007 & & & & & \\
\hline & $(-1.06)$ & & & & & \\
\hline \multirow[t]{2}{*}{ Moderate } & 0.080 & 0.090 & 0.090 & 0.07 & 0.076 & 0.086 \\
\hline & $(0.67)$ & $(0.76)$ & $(0.78)$ & $(0.68)$ & $(0.81)$ & $(0.80)$ \\
\hline \multirow[t]{2}{*}{ High } & 0.076 & 0.156 & 0.11 & 0.11 & 0.104 & 0.106 \\
\hline & $(0.88)$ & $(0.56)$ & $(0.92)$ & $(1.01)$ & $(0.78)$ & $(0.99)$ \\
\hline \multirow[t]{2}{*}{ Very high } & -0.366 & -0.366 & -0.377 & -0.367 & -0.378 & -0.380 \\
\hline & $(-2.67)^{* *}$ & $(-2.59)^{*}$ & $(-2.18)^{* *}$ & $(-1.67)^{*}$ & $(-2.21)^{* *}$ & $(-2.16)^{* *}$ \\
\hline \multirow{2}{*}{ Ln inflation } & -0.06 & -0.07 & -0.08 & -0.05 & -0.06 & -0.07 \\
\hline & $(-0.66)$ & $(-0.70)$ & $(-0.71)$ & $(-0.77)$ & $(-0.88)$ & $(-0.95)$ \\
\hline \multirow[t]{2}{*}{ Institution } & & -0.019 & & & & \\
\hline & & $(-1.17)$ & & & & \\
\hline \multirow[t]{2}{*}{ Political } & & & -0.006 & & & \\
\hline & & & $(-0.35)$ & & & \\
\hline \multirow[t]{2}{*}{ Democratic } & & & & 0.059 & & \\
\hline & & & & (1.17) & & \\
\hline \multirow[t]{2}{*}{ Investment } & & & & & -0.189 & \\
\hline & & & & & $(-1.17)$ & \\
\hline \multirow[t]{2}{*}{ Religion } & & & & & & -0.056 \\
\hline & & & & & & $(-1.01)$ \\
\hline \multirow[t]{2}{*}{ _Cons } & -19.89 & -18.88 & -19.06 & -19.19 & -18.99 & -19.156 \\
\hline & $(20.12)^{* * * *}$ & $(19.11)^{* * * *}$ & $(12.71)^{* * * *}$ & $(15.90)^{* * *}$ & $(14.89)^{* * *}$ & $(15.65)^{* * *}$ \\
\hline Groups & 39 & 39 & 39 & 39 & 39 & 39 \\
\hline Observations & 390 & 390 & 390 & 390 & 390 & 390 \\
\hline R2 (within) & 0.61 & 0.61 & 0.61 & 0.62 & 0.61 & 0.63 \\
\hline R2 (between) & 0.7405 & 0.7475 & 0.7460 & 0.7440 & 0.7506 & 0.7499 \\
\hline Bhargava DW stat. & 0.428 & 0.457 & 0.458 & 0.490 & 0.476 & 0.445 \\
\hline
\end{tabular}

Note: $\mathrm{t}$-values are reported in parentheses; ${ }^{* * *}=$ significant at 1 percent, ${ }^{* *}=$ significant at 5 percent, ${ }^{*}=$ significant at 10 percent. The Hausman test result for model 1 is $X^{2}=113.79$ $(p=0.00)$, the assumption being that we reject the use of random effects.

Source: Author's calculations.

Tables A3 and A4 employ difference GMM rather than system GMM. Although the latter improves efficiency, it also uses more instruments; given that the sample comprises 41 countries, system GMM is 
not an appropriate choice. The equation employs robust standard errors and the Hansen statistic to test the validity of the instruments used. In accordance with Roodman (2009), who suggests that the standard treatment for endogenous variables is to use the second lag and above, we use the second lag and its first difference as instruments.

Table A3: Arellano-Bond/Blundell-Bover panel data estimation

Dependent variable: $\ln$ FDI

\begin{tabular}{lllllll}
\hline Independent variable & Model 1 & Model 2 & Model 3 & Model 4 & Model 5 & Model 6 \\
\hline Lln FDI & 0.67 & 0.678 & 0.568 & 0.771 & 0.579 & 0.621 \\
& $(4.54)^{* * *}$ & $(11.54)^{* * *}$ & $(4.15)^{* * *}$ & $(11.87)^{* * *}$ & $(6.78)^{* * *}$ & $(4.79)^{* * *}$ \\
Moderate & & & & -0.016 & -0.027 & -0.014 \\
High & & & & $(-0.82)$ & $(-0.99)$ & $(-0.77)$ \\
& & & & 0.003 & -0.008 & -0.003 \\
Very high & & & & $(0.09)$ & $(-0.24)$ & $(-0.07)$ \\
& & -0.164 & -0.178 & -0.161 & -0.141 & -0.156 \\
Rating & & $(-2.74)^{* *}$ & $(-2.89)^{* * *}$ & $(-2.81)^{* *}$ & $(-1.82)^{*}$ & $(-2.67)^{* *}$ \\
& 0.009 & 0.008 & & & 0.001 & 0.006 \\
Ln GDP & $(1.45)$ & $(1.20)$ & & & $(0.22)$ & $(1.04)$ \\
& 0.726 & 0.567 & 0.89 & 0.79 & & 0.99 \\
Trade & $(2.50)^{* *}$ & $(1.99)^{* *}$ & $(2.42)^{* *}$ & $(2.42)^{* *}$ & & $(3.09)^{* * *}$ \\
& -0.155 & & & -0.107 & & 0.056 \\
Ln inflation & $(-0.80)$ & & & $(-0.32)$ & & $(0.23)$ \\
& -0.55 & & -0.16 & -0.12 & & \\
\hline Groups & $(-1.21)$ & & $(-0.99)$ & $(-0.77)$ & & \\
Instruments & 39 & 39 & 39 & 39 & 39 & 39 \\
Hansen test & 22 & 23 & 24 & 24 & 11 & 18 \\
Hansen p-values & 28.90 & 24.99 & 22.99 & 20.29 & 21.23 & 23.45 \\
AB test (z-values) & 0.069 & 0.080 & 0.047 & 0.095 & 0.020 & 0.047 \\
\hline Note: The results & -0.070 & -0.100 & 0.140 & -0.050 & -0.004 & 0.050 \\
\hline
\end{tabular}

Note: The results of the regression refer to one-step estimates; z-values are reported in parentheses; ${ }^{* * *}=$ significant at 1 percent,${ }^{* *}=$ significant at 5 percent,${ }^{*}=$ significant at 10 percent.

Source: Author's calculations. 


\section{Table A4: Arellano-Bond/Blundell-Bover panel data estimation after excluding BRIC countries from sample}

\begin{tabular}{|c|c|c|c|c|c|c|}
\hline \multirow{2}{*}{ Independent variable } & \multirow[b]{2}{*}{ Model 1} & \multicolumn{5}{|c|}{ Dependent variable: $\ln$ FDI } \\
\hline & & Model 2 & Model 3 & Model 4 & Model 5 & Model 6 \\
\hline Ln FDI & $\begin{array}{l}0.654 \\
(5.68)^{* * *}\end{array}$ & $\begin{array}{l}0.66 \\
(6.70)^{* * *}\end{array}$ & $\begin{array}{l}0.556 \\
(5.89)^{* * *}\end{array}$ & $\begin{array}{l}0.667 \\
(7.09)^{* * * *}\end{array}$ & $\begin{array}{l}0.667 \\
(7.88)^{* * *}\end{array}$ & $\begin{array}{l}0.59 \\
(4.77)^{* * *}\end{array}$ \\
\hline Moderate & $\begin{array}{l}-0.033 \\
(-1.66)\end{array}$ & $\begin{array}{l}-0.037 \\
(-1.85)^{*}\end{array}$ & $\begin{array}{l}-0.040 \\
(-1.86)^{*}\end{array}$ & $\begin{array}{l}-0.041 \\
(-1.70)^{*}\end{array}$ & $\begin{array}{l}-0.042 \\
(-1.80)^{*}\end{array}$ & $\begin{array}{l}-0.047 \\
(-1.85)^{*}\end{array}$ \\
\hline High & $\begin{array}{l}-0.020 \\
(-0.50)\end{array}$ & $\begin{array}{l}-0.020 \\
(-0.66)\end{array}$ & $\begin{array}{l}-0.012 \\
(-0.39)\end{array}$ & $\begin{array}{l}-0.022 \\
(-0.58)\end{array}$ & $\begin{array}{l}-0.021 \\
(-0.81)\end{array}$ & $\begin{array}{l}-0.019 \\
(-0.66)\end{array}$ \\
\hline Very high & $\begin{array}{l}-0.165 \\
(-2.17)^{* *}\end{array}$ & $\begin{array}{l}-0.166 \\
(-2.05)^{* * *}\end{array}$ & $\begin{array}{l}-0.171 \\
(-2.18)^{* *}\end{array}$ & $\begin{array}{l}-0.182 \\
(-2.89)^{* *}\end{array}$ & $\begin{array}{l}-0.155 \\
(-2.39)^{* * * *}\end{array}$ & $\begin{array}{l}-0.166 \\
(-2.40)^{* * * *}\end{array}$ \\
\hline Rating & $\begin{array}{l}0.005 \\
(1.03)\end{array}$ & & & & & \\
\hline Ln GDP & $\begin{array}{l}0.590 \\
(1.88)^{*}\end{array}$ & $\begin{array}{l}0.779 \\
(1.89)^{*}\end{array}$ & $\begin{array}{l}0.450 \\
(1.90)^{*}\end{array}$ & $\begin{array}{l}0.675 \\
(1.34)\end{array}$ & $\begin{array}{l}0.668 \\
(1.76)^{*}\end{array}$ & $\begin{array}{l}0.789 \\
(1.85)^{*}\end{array}$ \\
\hline Trade & $\begin{array}{l}-0.040 \\
(-0.24)\end{array}$ & $\begin{array}{l}-0.068 \\
(-0.44)\end{array}$ & $\begin{array}{l}-0.054 \\
(-0.31)\end{array}$ & $\begin{array}{l}-0.063 \\
(-0.38)\end{array}$ & $\begin{array}{l}-0.094 \\
(-0.58)\end{array}$ & $\begin{array}{l}-0.074 \\
(-0.47)\end{array}$ \\
\hline Ln inflation & $\begin{array}{l}-0.04 \\
(-0.78)\end{array}$ & $\begin{array}{l}-0.05 \\
(-0.80)\end{array}$ & $\begin{array}{l}-0.09 \\
(-1.01)\end{array}$ & $\begin{array}{l}-0.07 \\
(-0.98)\end{array}$ & $\begin{array}{l}-0.08 \\
(-0.99)\end{array}$ & $\begin{array}{l}-0.04 \\
(-0.77)\end{array}$ \\
\hline Institution & & $\begin{array}{l}0.008 \\
(0.81)\end{array}$ & & & & \\
\hline Political & & & $\begin{array}{l}0.016 \\
(0.89)\end{array}$ & & & \\
\hline Democratic & & & & $\begin{array}{l}0.018^{* *} \\
(2.05)\end{array}$ & & \\
\hline Investment & & & & & $\begin{array}{l}0.028 \\
(1.04)\end{array}$ & \\
\hline Religion & & & & & & $\begin{array}{l}0.056 \\
(2.88)^{* *}\end{array}$ \\
\hline Groups & 35 & 35 & 35 & 35 & 35 & 35 \\
\hline Instruments & 25 & 25 & 25 & 25 & 25 & 25 \\
\hline Hausman test & 23.19 & 24.22 & 23.39 & 23.79 & 24.22 & 23.39 \\
\hline Hansen p-values & 0.129 & 0.166 & 0.174 & 0.168 & 0.134 & 0.170 \\
\hline AB test (z-values) & 0.330 & 0.520 & 0.380 & 0.310 & 0.220 & 0.330 \\
\hline
\end{tabular}

Note: The results of the regression refer to one-step estimates; $z$-values are reported in parentheses; ${ }^{* * *}=$ significant at 1 percent, ${ }^{* *}=$ significant at 5 percent, ${ }^{*}=$ significant at 10 percent.

Source: Author's calculations. 


\section{Appendix 2}

We take the proportionate difference in FDI between countries with a very high level of expected future turmoil risk and a low level of expected future turmoil risk as follows:

Log (FDI inflows of very high expected future turmoil risk) $-\log$ (FDI inflows of low expected future turmoil risk) $=-$ 16 percent

Exponentiation and subtracting 1 yields:

(FDI inflows of very high expected future turmoil risk FDI inflows of low expected future turmoil risk)/FDI inflows of low expected future turmoil risk $=\exp (-0.16)-$ $1=-0.147$

This more accurate estimate implies that a country with a very high level of expected future turmoil risk has, on average, 16.63 percent lower FDI inflows than a country with a low level of expected future turmoil risk. 